\title{
Depresi: Ciri, Penyebab dan Penangannya
}

\author{
Oleh: \\ Aries Dirgayunita \\ (Sekolah Tinggi Agama Islam Muhammadiyah Probolinggo)
}

\begin{abstract}
Abstrak
Setiap orang pasti mengalami berbagai masalah dan rintangan dalam hidupnya. Jika seseorang dalam hidupnya mudah putus asa dan tidak kuat menghadapi masalah hidupnya, orang tersebut bisa mengalami depresi bahkan bisa menjadi stress. Depresi bukan saja dialami oleh orang dewasa tetapi anak-anak juga bisa mengalami depresi yang tidak mengenal kelas sosial. Banyak faktor yang menyebabkan seseorang menjadi depresi dan terpuruk. Depresi merupakan salah satu penyebab utama kejadian bunuh diri (suicide). Sebanyak $40 \%$ penderita depresi mempunyai ide untuk bunuh diri, dan hanya lebih kurang $15 \%$ saja yang sukses melakukannya. WHO memprediksikan bahwa pada tahun 2020, depresi akan menjadi salah satu gangguan mental yang banyak dialami dan depresi berat akan menjadi penyebab kedua terbesar kematian setelah serangan jantung. Berdasarkan data WHO tahun 1980, hamper $20 \%$ - 30\% dari pasien rumah sakit di Negara berkembang mengalami gangguan mental emosional seperti depresi. Depresi merupakan gangguan emosional atau suasana hati yang buruk yang ditandai dengan kesedihan yang berkepanjangan, putus harapan, perasaan bersalah dan tidak berarti. Sehingga seluruh proses mental (berpikir, berperasaan dan berperilaku) tersebut dapat mempengaruhi motivasi untuk beraktivitas dalam kehidupan sehari-hari maupun pada hubungan interpersonal.
\end{abstract}

Kata Kunci: Gangguan jiwa, Depresi, ciri depresi dan penyebab depresi. 


\section{Abstraks}

Each person must have experienced a variety of problems and obstacles in his life. If someone in his life is hopeless and strength to face the problems of life, the person may experience depression can even become stressful. Depression is not only experienced by adults but children may also experience depression knows no social class. Many factors that cause a person to become depressed and down. Depression is one of the main causes of suicide (suicide). As many as $40 \%$ of patients with depression have suicidal ideas, and only approximately $15 \%$ that succeed do so. WHO predicts that by 2020 , depression will be one of the more experienced of mental disorders and severe depression will be the second largest cause of death after a heart attack. Based on data from the WHO in 1980 , nearly $20 \%-30 \%$ of hospital patients in developing countries mental emotional disorder such as depression. Depression is an emotional disorder or a bad mood characterized by prolonged sadness, hopelessness, guilt and does not mean. So that all mental processes (thinking, feeling and behaving) can affect the motivation to move in daily life and in interpersonal relationships.

Keywords: Mental disorders, depression, depression characteristics and causes of depression.

\section{Pendahuluan}

Saat ini, banyak orang yang mengalami stress, kecemasan, galau dan kegelisahan yang berlarut-larut. Namun, sebagian besar orang berpikir dan beranggapan bahwa stress dan depresi, bukanlah benar-benar suatu gangguan mental. Mereka menganggap bahwa depresi adalah sesuatu yang sepele dan bisa hilang dengan sendirinya, padahal sebenarnya depresi adalah bentuk suatu gangguan yang lebih dari sekadar perubahan emosi sementara. Depresi bukanlah kondisi yang bisa diubah dengan cepat atau secara langsung.

Setiap orang pasti mengalami berbagai masalah dan rintangan dalam hidupnya. Jika seseorang dalam hidupnya 
mudah putus asa dan tidak kuat menghadapi masalah hidupnya, orang tersebut bisa mngelami depresi bahkan bisa menjadi stress. Depresi bukan saja dialami oleh orang dewasa tetapi anak-anak juga bisa mengalami depresi yang tidak mengenal kelas sosial. Banyak faktor yang menyebabkan seseorang menjadi depresi dan terpuruk. Depresi merupakan salah satu penyebab utama kejadian bunuh diri (suicide). Sebanyak $40 \%$ penderita depresi mempunyai ide untuk bunuh diri, dan hanya lebih kurang $15 \%$ saja yang sukses melakukannya.

Jumlah penderita depresi wanita dua kali lebih banyak dari pria, tetapi pria lebih berkecenderungan bunuh diri. Di Amerika Serikat, $17 \%$ orang pernah mengalami depresi pada suatu saat dalam hidup mereka, dengan jumlah penderita saat ini lebih dari 19 juta orang. Depresi merupakan salah satu masalah kesehatan mental utama saat ini, yang mendapat perhatian serius. Dinegara-negara berkembang, WHO memprediksikan bahwa pada tahun 2020, depresi akan menjadi salah satu gangguan mental yang banyak dialami dan depresi berat akan menjadi penyebab kedua terbesar kematian setelah serangan jantung. Berdasarkan data WHO tahun 1980, hamper 20\% - 30\% dari pasien rumah sakit di Negara berkembang mengalami gangguan mental emosional seperti depresi.

Depresi dan stress yang dibiarkan berlarut membebani pikiran, dapat mengganggu system kekebalan tubuh. Apabila kita berada dalam emosi yang negatif seperti rasa sedih, benci, putus asa, iri, kecemasan, dan kurang bersyukur maka sistem kekebalan kita menjadi lemah. Dalam suatu penelitian di amerika, 28 dari 32 orang pasien telah mengalami stres dan kehidupan yang tragis sebelum terserang penyakit. Stres mental ini mengakibatkan system kekebalan tubuh menjadi tidak normal. Para doketr di John Hopkin Medical School menemukan bahwa orang - orang yang emosional dan pemurung cenderung menderita penyakit yang serius seperti kanker, tekanan darah tinggi, jantung dan berumur pendek. 


\section{Apa Yang Dimaksud Dengan Depresi}

Depresi merupakan kondisi emosional yang biasanya ditandai dengan kesedihan yang amat sangat, perasaan tidak berarti dan bersalah (menarik diri, tidak dapat tidur, kehilangan selera, minat dalam aktivitas sehari-hari), dalam Gerald C. Davison 2004. Menurut Rice PL (1992), depresi adalah gangguan mood, kondisi emosional berkepanjangan yang mewarnai seluruh proses mental (berpikir, berperasaan dan berperilaku) seseorang. Pada umumnya mood yang secara dominan muncul adalah perasaan tidak berdaya dan kehilangan harapan.

Menurut lyus Yosep (2007), depresi adalah salah satu bentuk gangguan jiwa pada alam perasaan (afektif, mood) yang ditandai kemurungan, kesedihan, kelesuan, kehilangan gairah hidup, tidak ada semangat, dan merasa tidak berdaya, perasaan bersalah atau berdosa, tidak berguna dan putus asa. Chaplin (2002) mendefinisikan depresi pada dua keadaan, yaitu pada orang normal dan pada kasus patologis. Pada orang normal, depresi merupakan keadaan kemurungan (kesedihan, kepatahan semangat) yang ditandai dengan perasaan tidak pas, menurunnya kegiatan, dan pesimisme menghadapi masa yang akan datang. Sedangkan pada kasus patologis, depresi merupakan ketidakmauan ekstrim untuk mereaksi terhadap perangsang, disertai menurunnya nilai diri, delusi ketidakpasan, tidak mampu dan putus asa.

Sedangkan menurut Kartono (2002), depresi adalah kemuraman hati (kepedihan, kesenduan, keburaman perasaan) yang patologis sifatnya. Biasanya timbul oleh; rasa inferior, sakit hati yang dalam, penyalahan diri sendiri dan trauma psikis. Jika depresi itu psikotis sifatnya, maka disebut melankholi.

Berdasarkan beberapa definisi di atas, dapat disimpulkan bahwa depresi merupakan gangguan emosional atau suasana hati yang buruk yang ditandai dengan kesedihan yang berkepanjangan, putus harapan, perasaan bersalah dan tidak berarti. Sehingga seluruh proses mental (berpikir, berperasaan dan berperilaku) tersebut dapat mempengaruhi motivasi untuk beraktivitas dalam kehidupan sehari-hari maupun pada hubungan interpersonal.. 


\section{Ciri-ciri dan Gejala- ejala Depresi}

Pada umumnya, individu yang mengalami depresi menunjukkan gejala psikis, fisik dan sosial yang khas. Beberapa orang memperlihatkan gejala yang minim, beberapa orang lainnya lebih banyak. Tinggi rendahnya gejala bervariasi dari waktu ke waktu. Menurut Institut Kesehatan Jiwa Amerika Serikat (NIMH) dan Diagnostic and Statistical manual IV - Text Revision (DSM IV - TR) (American Psychiatric Association, 2000). Kriteria depresi dapat ditegakkan apabila sedikitnya 5 dari gejala dibawah ini telah ditemukan dalam jangka waktu 2 minggu yang sama dan merupakan satu perubahan pola fungsi dari sebelumnya. Gejala dan tanda umum depresi adalah sebagai berikut :

\section{Gejala Fisik}

1. Gangguan pola tidur; Sulit tidur (insomnia) atau tidur berlebihan (hipersomnia)

2. Menurunnya tingkat aktivitas, misalnya kehilangan minat, kesenangan atas hobi atau aktivitas yang sebelumnya disukai.

3. Sulit makan atau makan berlebihan (bisa menjadi kurus atau kegemukan)

4. Gejala penyakit fisik yang tidak hilang seperti sakit kepala, masalah pencernaan (diare, sulit BAB dll), sakit lambung dan nyeri kronis

5. Terkadang merasa berat di tangan dan kaki

6. Energi lemah, kelelahan, menjadi lamban

7. Sulit berkonsentrasi, mengingat, memutuskan

\section{Gejala Psikis}

1. Rasa sedih, cemas, atau hampa yang terus - menerus.

2. Rasa putus asa dan pesimis

3. Rasa bersalah, tidak berharga, rasa terbebani dan tidak berdaya/tidak berguna

4. Tidak tenang dan gampang tersinggung

5. Berpikir ingin mati atau bunuh diri

6. Sensitive

7. Kehilangan rasa percaya diri 


\section{Gejala Sosial}

1. Menurunnya aktivitas dan minat sehari-hari (menarik diri, menyendiri, malas)

2. Tidak ada motivasi untuk melakukan apapun

3. Hilangnya hasrat untuk hidup dan keinginan untuk bunuh diri

\section{Penyebab Depresi}

Depresi disebabkan oleh kombinasi beberapa faktor. Jika seseorang di dalam riwayat kesehatannya memiliki keluarga yang mengalami depresi, maka terdapat kecenderungan untuk mengalami depresi juga. Menurut Kaplan (2002) dan Nolen - Hoeksema \& Girgus (dalam Krenke \& Stremmler, 2002), faktor - faktor yang dihubungkan dengan penyebab dapat dibagi atas : faktor biologi, faktor psikologis/kepribadian dan faktor sosial. Dimana ketiga faktor tersebut dapat saling mempengaruhi satu dengan yang lainnya.

\section{Faktor Biologi}

Beberapa peneliti menemukan bahwa gangguan mood melibatkan patologik dan system limbiks serta ganglia basalis dan hypothalamus. Dalam penelitian biopsikologi, norepinefrin dan serotonin merupakan dua neurotrasmiter yang paling berperan dalam patofisiologi gangguan mood. Pada wanita, perubahan hormon dihubungkan dengan kelahiran anak dan menoupose juga dapat meningkatkan risiko terjadinya depresi. Penyakit fisik yang berkepanjangan sehingga menyebabkan stress dan juga dapat menyebabkan depresi.

\section{Faktor Psikologis/Kepribadian}

Individu yang dependent, memiliki harga diri yang rendah, tidak asertif, dan menggunakan ruminative coping. Nolen - Hoeksema \& Girgus juga mengatakan bahwa ketika seseorang merasa tertekan akan cenderung fokuspada tekanan yang mereka rasa dan secara pasif merenung daripada 
mengalihkannya atau melakukan aktivitas untuk merubah situasi.

Pemikiran irasional yaitu pemikiran yang salah dalam berpikir seperti menyalahkan diri sendiri atas ketidak beruntungan. Sehingga individu yang mengalami depresi cenderung menganggap bahwa dirinya tidak dapat mengendalikan lingkungan dan kondisi dirinya. Hal ini dapat menyebabkan pesimisme dan apatis.

\section{Faktor Sosial}

1. Kejadian tragis seperti kehilangan seseorang atau kehilangan dan kegagalan pekerjaan

2. Paska bencana

3. Melahirkan

4. Masalah keuangan

5. Ketergantungan terhadap narkoba atau alkhohol

6. Trauma masa kecil

7. Terisolasi secara sosial

8. faktor usia dan gender

9. tuntutan dan peran sosial misalnya untuk tampil baik, menjadi juara di sekolah ataupun tempat kerja

10. Maupun dampak situasi kehidupan sehari-hari lainnya.

\section{Risiko yang Ditimbulkan Akibat Depresi}

1. Bunuh Diri

Orang yang menderita depresi memiliki perasaan kesepian, ketidakberdayaan dan putus asa. Sehingga mereka mempertimbangkan membunuh dirinya sendiri.

2. Gangguan Tidur :

Insomnia ataupun hypersomnia, Gangguan tidur dan depresi biasanya cenderung muncul bersamaan. Setidaknya $80 \%$ dari orang yang menderita depresi mengalami insomnia atau kesulitan untuk tidur. $15 \%$ mengalami depresi dengan tidur yang berlebihan. Kesulitan tidur dianggap sebagai gejala gangguan mood.

3. Gangguan Interpersonal

Individu yang mengalami depresi cenderung mudah tersinggung, sedih yang berkepanjangan sehingga cenderung menarik diri dan menjauhkan diri dari orang 
lain. Terkadang menyalahkan orang lain. Hal ini menyebabkan hubungan dengan orang lain maupun lingkungan sekitar menjadi tidak baik.

4. Gangguan dalam pekerjaan

Depresi meningkatkan kemungkinan dipecat atau penderita sendiri yang mengundurkan diri dari pekerjaan ataupun sekolah. Orang yang menderita depresi cenderung memiliki motivasi yang menurun untuk melakukan aktivitas ataupun minat pekerjaan dalam kehidupan sehari-hari.

5. Gangguan pola makan

Depresi dapat menyebabkan gangguan pola makan atau sebaliknya gangguan pola makan juga dapat menyebabkan depresi. Pada penderita depresi terdapat dua kecenderungan umum menegenai pola makan yang secara nyata mempengaruhi berat tubuh yaitu :

a. Tidak selera makan

b. Keinginan makan-makanan yang manis bertambah

6. Perilaku-perilaku merusak

Beberapa orang yang menderita depresi memiliki perilaku yang merusak seperti, agresivitas dan kekerasan, menggunakan obat-obatan terlarang dan alkhohol, serta perilaku merokok yang berlebihan.

\section{Macam Gangguan Depresi}

Gangguan depresi terbagi menjadi dua, yaitu:

1. Major Depressive Disorder (MDD)

MDD ditandai dengan kondisi emosi sedih dan kehilangan kemampuan untuk menikmati aktivitas yang biasa dilakukan, bersama dengan minimal 4 (empat) dari gejala di bawah ini :

a. Tidur terlalu banyak (10 jam atau lebih) atau terlalu sedikit (sulit untuk tertidur, sering terbangun)

b. Kekakuan motorik

c. Kehilangan nafsu makan dan berat badan menurun drastisatau sebaliknya makan berlebihan sehingga berat badan meningkat drastis.

d. Kehilangan energy, lemas, tidak bersemangat, tidak tertarik melakukan apapun 
e. Merasa tidak berharga

f. Kesulitan untuk berkonsentrasi, berpikir, dan membuat keputusan

g. Muncul pikiran tentang kematian berulang kali atau bunuh diri

Gejala-gejala ini muncul hamper sepanjang hari, setiap hari, selama minimal 2 (dua) minggu dan bukan dikarenakan kehilangan yang wajar, misalnya karena suami/istri meninggal. MDD sering disebut masyarakat umumdengan istilah depresi.

\section{Dysthymic Disorder (Gangguan Distimik/Distimia)}

Merupakan gangguan depresi yang kronis. Individu yang didiagnosis mengalami distimik mengalami kondisi depresif lebih dari separuh waktu dari minimal 2 (dua) tahun. Jadi, dalam jangka waktu 2 (dua) tahun, separuh dari waktu tersebut individu ini mengalami kondisi depresif, minimal mengalami 2 (dua) gejala di bawah ini :
a. Kehilangan nafsu makan atau sebaliknya
b. Tidur terlalu banyak/terlalu sedikit
c. Merasa diri tidak berharga
d. Kesulitan berkonsentrasi dan mengambil keputusan
e. Mersa kehilangan harapan

Gejala tidak tampak jelas lebih dari 2 (dua) bulan. Tidak ada episode MDD selama 2 tahun pertama gejala muncul. Gejala yang dialami lebih ringan daripada MDD namun dengan waktu yang lebih lama.

\section{Penanganan Depresi}

Depresi dapat ditangani dengan perubahan pola hidup, terapi psikologi, dan dengan pengobatan (obat antiretroviral/ARV). Dilarang keras mengomati diri sendiri dengan alkhohol, merokok yang berlebihan dan narkoba, karena zat yang terkandung di dalamnya dapat meningkatkan gejala depresi dan menimbulkan masalah lain. Berikut beberapa cara penanganan depresi :

1. Perubahan pola hidup

a. Berolahraga 
Orang yang menderita depresi mengalami stress, kecemasan, galau, kebingungan dan kegelisahan yang berlarut - larut. Hal ini disebabkan oleh pikiran dan perasaan yang negatif. Salah satu cara yang dapat dilakukan untuk menghasilkan pikiran dan perasaan positif yang dapat menghalangi munculnya mood negatif adalah dengan berolahraga.

b. Mengatur pola makan

Simptom depresi dapat diperparah oleh ketidakseimbangan nutrisi di dalam tubuh, yaitu:

1) Konsumsi kafein secara berkala

2) Konsumsi sukrosa (gula)

3) Kekurangan biotin, asam folat, vitamin B, C, kalsium, magnesium atau kelebihan magnesium dan tembaga

4) Ketidakseimbangan asam amino

5) Alergi makanan

c. Berdoa

Beberapa orang mempunyai kecenderungan untuk berpaling dari agama dalam memperoleh kekuatan dan hiburan. Dengan berdoa seseorang melakukan dan mengucap rasa syukur kepada Tuhan YME.

d. Memiliki keberanian untuk berubah

Penderita depresi harus memiliki keberanian untuk melewati kegelapan menuju terang, keberanian untuk berubah.

e. Rekreasi

Berjalan-jalan di tempat yang asri, menyejukkan agar tubuh dan pikiran menjadi lebih rileks dan nyaman. Selain itu, melakukan aktivitas yang menjadi minat sebelumnya seperti, membaca buku, memasak, memancing dll yang bisa membuat penderita menjadi rileks dan nyaman.

2. Terapi psikologi

a. Terapi Interpersonal

Bantuan psikoterapi bisa dilakukan oleh psikolog dalam jangka pendek yang berfokus kepada hubungan 
antara orang-orang dengan perkembangan symptom gangguan kejiwaan.

b. Konseling kelompok dan dukungan sosial

Mengunjungi tempat layanan bimbingan konseling. Pelaksaan wawancara konseling yang dilakukan antara seorang konselor professional dengan beberapa pasien sekaligus dalam kelompok kecil.

c. Terapi humor

Profesional medis yang membantu pasien untuk mempertahankan sikap mental yang positif dan berbagai tawa merespons psikologis dari tertawa termasuk meningkatkan pernafasan, sirkulasi, sekresi hormone, enzim pencernaan, dan peningkatan tekanan darah.

d. Terapi Kognitif (CBT)

Pendekatan CBT memusatkan perhatian pada proses berpikir klien yang berhubungan dengan kesulitan emosional dan psikologi klien. Pendekatan ini akan berupaya membantu klien mengubah pikiran-pikiran atau pernyataan diri negatif dan keyakinan-keyakinan pasien yang tidak rasional. Fokus dalam teori ini adalah mengganti cara-cara berfikir yang tidak logis menjadi logis.

3. Pengobatan

Berkonsultasi kepada dokter kejiwaan/psikiater. Beberapa obat antidepresan yaitu: lithium, MAOls, Tricyclics. Beberapa psikiater meresepkan perangsang jiwa (psychostimulant), obat yang dipakai untuk mengobati gangguan deficit perhatian (attention deficit disorder).

\section{Pencegahan Depresi}

Beberapa cara mencegah depresi agar tidak terjadi atau tidak datang kembali adalah sebagai berikut:

1. Bersikap realistis terhadap apa yang kita harapkan dan apa yang bisa kita lakukan.

2. Tidak menyalahkan diri sendiri atau orang lain saat kita melakukan suatu kesalahan atau mengalami kegagalan. 
3. Tidak membanding-bandingkan diri dengan orang lain ataupun kehidupan orang lain.

4. Pikirkan untuk menyimpan keputusan besarsampai sembuh dari depresi, seperti menikah, bercerai, tentang pekerjaan atau sekolah. Bicarakanlah dengan teman, professional (psikolog, konselor atau psikiater)atau orang yang kita sayangi atau kita anggap mampu membantu untuk melihat gambaran besarnya.

5. Dukungan keluarga, social dengan mengatakan jika kita mengalami masalah atau sedang mengalami depresi.

6. Rutin lakukan olahraga dan kegiatan outdoor

7. Tidak terlalu menyesali suatu kejadian, bersikap tenang dan tidak mudah marah

8. Bangunlah harga diri dan mencoba bersikap dan berpikir positif.

9. Tidak menyendiri, menjauhi diri dari pergaulan, lebih bersosialisasi, melakukan aktivitas dengan lingkungan sekitar

10. Lebih religious, mendekatkan diri kepada Tuhan YME

\section{Kesimpulan}

Depresi adalah gangguan emosional atau suasana hati yang buruk yang ditandai dengan kesedihan yang berkepanjangan, putus harapan, perasaan bersalah dan tidak berarti. Sehingga seluruh proses mental (berpikir, berperasaan dan berperilaku) tersebut dapat mempengaruhi motivasi untuk beraktivitas dalam kehidupan sehari-hari maupun pada hubungan interpersonal.

Individu yang mengalami depresi pada umumnya menunjukkan gejala fisik, gejala psikis, dan gejala sosial yang khas. Depresi disebabkan oleh kombinasi beberapa factor, yaitu faktor biologi, faktor psikologis/kepribadian dan faktor sosial. Dimana ketiga faktor tersebut dapat saling mempengaruhi satu dengan yang lainnya. 


\section{Daftar Pustaka}

Aditomo, A. \& Retnowati, S. (2004). Perfeksionisme, harga diri, dan kecenderungan depresi pada remaja akhir. Jurnal Psikologi (1), 1-15.

Brehm, S. (2002). Intimate Relationship. New York : Mc. Graw Hill.

Chaplin, J. P. (2002). Kamus Lengkap Psikologi. Jakarta : PT. Raja Grafindo Persada.

Davison, T.E \& McCabe, M. P. (2006). Adolescent Body Image And Psychosocial Functioning. The journal of social psychology, 146 (1), 15-30.

Depresi. (spiritia. or. id).

Depresi-gejala dan cara mengobati. (alodokter. htm).

Depresi-gejala, ciri, penyebab dan terapi menghilangkan depresi. file:///D:/Depresi.htm

Kaplan dan Sadock. (2002). Sinopsis Psikiatri, IImu Pengetahuan Perilaku Psikiatri Klinis, edisi ketujuh, jilid satu. Jakarta: Binarupa Aksara.

Kring, Johson, Davison \& Neale. (2004). Edisi kesembilan. Jakarta: PT Raja Grafindo Persada. Divisi Buku Perguruan Tinggi.

Kring, Johson, Davison \& Neale. (2009). Abnormal Psychology. Eleventh edition. Berkeley: John wiley \& Sons. 
$14 \sim$ Depresi: Ciri, Penyebab

Nevid, Spencer A. Rathus \& Beverly Greene. (2002). Psikologi Abnormal, edisi kelima, jilid 1. Jakarta: Penerbit Erlangga.

Yosep lyus. (2007). Keperawatan Jiwa. Bandung: PT. Refika Aditama. 